\title{
Impact of drought and conflicts on women's livelihoods in Al Goz Locality - South Kordofan State- Sudan
}

\author{
Dr. Elshifa A. Merghani- Supervisor, Dr. Fatima Ezzedlin- Co-supervisor, \\ Elhabib Hamdok- Researcher
}

\begin{abstract}
Drought and conflicts in Al Goz locality have made life more difficult for almost everyone living person there but women and girls are in a unique position. An attempt was made in this paper to look into some important trends of women participation in livelihood activities in a period of ten years of crises (drought and conflicts from 2000 to 2010). Primary data was collected by random sampling (75 women) from ten villages in Al Goz locality using structured interviewing technique as well as semi-structured interviews carried out with eight (8) women (household headed family, key informants and/or active women in the village. Furthermore six discussion groups covering 36 female participants were also conducted. The study concluded that the crises; drought and conflicts forced young women and their children (as productive members in families to migrate and look for jobs and new source of income. This migration made women subject to exploitation, hard labour, family break ups with very little earnings at the end.
\end{abstract}

Key words: Drought and conflicts, livelihood activities, coping strategies.

\section{Introduction}

Most people in the third world live in rural areas. In developing countries of Africa, rural population who reside in the country-side most of them engaged in agricultural and the majority are poor. Increasing attention is also being given to the role of smallholder subsistence agriculture where women are dominating in ensuring the food security of the continent, as $73 \%$ of the rural population consists of smallholder farmers. In Sub-Saharan Africa, agriculture accounts for approximately $21 \%$ of the continent's GDP and women contribute $60-80 \%$ of the labour used to produce food both for household consumption and for sale. (FAO: 1994)

Indeed it can be argued that in terms of population employment and production, agriculture is the most important sector. Agriculture in its broad terms refers to human activities in farming whether animal husbandry that is defined as rearing of livestock, cultivation of crops and vegetables and the processing of agricultural products which governed by different climates, culture and technological innovations to sustain life (UNDP report: 2002).

In south Kordofan as reported by Karim Hussein (2004); Agriculture represents the main livelihood strategy where cotton, groundnuts (peanuts), sorghum, millet, gum Arabic, sugar cane, cassava, mango, bananas, sweet potatoes, sesame grown and at least more than half the number of livestock $(17,025,000$ heads) are reared.

Drought and conflicts have adversely impacted on people, especially women and posed significant threat to female pastoral and farming livelihoods. The area experienced loss of human and property, reduction in livestock numbers limited to water and resources, food shortage, malnutrition and diseases, closure of markets and schools, and forced migration (ministry of cabinet affairs: 2008). operational:

The Ojos Negro Research Group (2007) came up with two types of drought definitions; conceptual and

- "Conceptual definitions helps to understand the meaning of drought and its effects, for example; drought is protracted period of deficient precipitations which causes entire damage to crops and resulting in loss of yield.

- Operational definition helps identifying drought beginning, end, and degree of severity"

The literature discussed impacts of drought on humans during the few past years in two ways: direct impact which include direct reduction of crops, rangeland, and forest productivity and also increased fire hazard, reduced water levels, increased livestock and wildlife mortality rates and damage to wildlife and fishery habitat. The consequences of these direct impacts results in indirect impacts such as reduction in the quality and yield of crops, reduced forest and rangeland lessened farmers income, increase prices goods and services, reduced tax /collections revenues as expenditure need to be reduced, stopping of bank credits and loans to farmers, migration and disaster relief programs. (The Peace Crops Center 2001)

The Peace Crops Center (2001) also listed the effects of drought as economic, environmental and social: 
- $\quad$ The economic effect as the loss of notional economic growth, which slows down the economic development

- Environmental effects as increased desertification which causes damage to crops and animal species

- Social effects such as mental and physical stresses"

\section{Conflicts and impacts:}

Conflict is a struggle between two or more forces which creates a tension that must be resolved. Galteng (1996) viewed conflict as a triangle with structure, attitude and behaviour as its varices. By structure he means the conflict situation, the parties and conflict interest between them. A conflict arises when the parties come to have incompatible interests, values or goals.

SIHA Group (2007) argued that conflicts are not always bad. They came up with positive conflicts. A conflict does not always mean violence but it may become struggle in interests. Parties in conflict can use violent act to articulate their right to having some at the human rights. This makes conflict as a positive phenomenon as it will be an important tool in the process of social transformation.

Galteng (1996) summarized the impact of conflicts as follows:

- $\quad$ "Loss of public entitlements

- Loss of market /livelihoods entitlements

- Loss of civil/social entitlements

- Reverse entitlements/ new form of social inequity/ inequality"

History of conflicts and drought in the study area:

The study covered part of South Kordofan State (SKS) which delineated by North Kordofan State, the South Darfur and Unity States in the west, South Sudan and Upper Nile in the South, and the White Nile at the East. Al Goz locality, the area of the study,contains 54 villages situated in the poor savannah area where average accumulative annual rainfall does not exceed $300 \mathrm{~mm}$ without even distribution and in some seasons it goes down to less than $150 \mathrm{~mm}$. the total population is 47,435 persons. Gender disaggregated as $25,141(53 \%)$ females and 22,294 (47\%) males. (District records: 2011).

Over a period of time from 1970 to 2010, Al Goz locality experienced serious deterioration of resources, and the beginning of what is termed as desertification has appeared since 1974. Conflicts erupted in Southern Sudan, Darfur regions and recent in Southern Kordofan have driven a huge number of people to the locality. It is recorded that the area has been experiencing a range of drought in the past thirty (30) years. Drought hit the area in 1984, 1990, and 2006 and of recent in 2011.Drought always followed by food insecurity. (Locality metrological records: 2008)

Of recent, the locality was dry where the annual rainfall did not exceed $250 \mathrm{~mm}$ in all the areas of the locality. This seriously affected the production of crops, and livestock and the income of the residents at large. (District metrological records: 2011/2012). It is stated by the locality Commissioner that the locality suffered the effect of drought from 1970, as well as conflicts where internal displaced people (IDPs) have come from Southern Sudan, southern localities of Southern Kordofan and from Darfur region consequently affected the livelihoods and livelihood mechanisms of the peoples of the locality. Those conflicts are:

- $\quad$ Fighting between nomads and settlers (farmers and cattle herders)

- Land disputes especially on the demarcation of farming plots

- $\quad$ Rebels and government fighting and wars

Many families from South Sudan and Southern areas of South Kordofan State came and lived in with their relatives in Dubeibat -Capital of the locality during SPLA and government fighting at Abyei and Hejlig oil producing areas. Due to Darfur crises many people as well have come and resided in Al Goz locality and surrounding villages. (State Commissioner: 2012)

Drought and conflicts have adversely impacted on people and especially on women who represent a large part of the working force. Women and girls constitute a substantial economic resource in agricultural sector and other off-farm livelihood activities. Drought and conflicts posed significant threat to females' pastoral livelihoods as well.

Therefore, the main purpose of this paper is to assess the impact of drought and conflicts on women's livelihood activities and identify adaptive strategies and mechanisms used during the years of crises from 20002010.

\section{Objectives of the paper:}

- $\quad$ To asses types of assets lost and causes of loss

- To identify the coping mechanisms and strategies employed women to mitigate crises negative impacts 


\section{Research Focus and Methodology}

For this study, data have been collected using a combination of two methodologies qualitative and quantitative methods supplementing each other and from 10 villages of the total 54 villages of the locality during July - August 2013.

A simple random sampling is used in selecting 75 women from the ten villages. The respondents were those who experienced drought and conflicts for an extended period of (5) years or more.Quantitative sampling refers to the process of selecting a sample from a defined population with the intent that the sample accurately represents that population. Bogdan, (1982) defines random sampling as "a group of individuals drawn by a procedure in which all the individuals in the defined population have an equal and independent chance of being selected as a member of the sample".A questionnaire has been used to collected data of key questions concerned with discovering the nature of drought and conflicts as it exists in $A L G o z$ locality and assesses the adaptive strategies and livelihood mechanisms used by women.

For the qualitative data, a qualitative methodology is used and data was collected through focal group discussions (FGDs). Six (6) women groups (6 members per a group) representing the (10) villages selected through a purposeful sampling. Borg (1996) described this way ofsampling saying that "the purposeful sampling is not designed to achieve population validity. The intent is to achieve an in-depth understanding of the selected individuals, i.e. Not to select a sample that represents accurately a defined population". With the same sampling procedure (purposeful), eight (8) women were selected for interviews (in some villages women were not allowed to meet strangers).

The respondents of the study have suffered repeated crises of drought and conflicts. They lived for several years together and performed the same agric-economical and other livelihood activities. The study employed a descriptive analysis for the qualitative dataand statistical analysis for the quantitative data.

\subsection{Demographic structure}

\section{Results and Discussions}

The demographic component of this study covered age, education, marital status, family members, residence and occupation. These components were set to clarify how does the demographic structure affects the transformation and coping mechanisms.

Table: 3.1 frequency distribution and percentage of respondents by age

\begin{tabular}{|c|c|c|}
\hline Age group & Frequency & Percentage \\
\hline Less than 15 years & 0 & 0 \\
\hline $16-25$ years & 11 & 15 \\
\hline $26-35$ years & 23 & 31 \\
\hline $36-45$ years & 25 & 15 \\
\hline $46-55$ years & 11 & 6 \\
\hline 56 and above & 5 & 100 \\
\hline Total & 75 & \\
\hline
\end{tabular}

Source: study survey 2013

As shown in table 3.1 above $79 \%$ of the respondents interviewed in the questionnaires their age ranges between 26- 55 years with only $6 \%$ aged 56 years and above. This shows that the background, experience and maturity well matched the capabilities to respond to the administered questionnaires. The table also indicated that 70 of the respondents (94\%) their age falls between 16- 55 years, they represent active economic driving force in terms of production as well as consumption at the locality.

Table: 3.2 frequency distribution and percentage of respondents by their educational level

\begin{tabular}{|c|c|c|}
\hline Level of education & Frequency & Percentage \\
\hline Illiterate & 25 & 33 \\
\hline Khalwa & 5 & 7 \\
\hline Primary school & 17 & 23 \\
\hline Secondary school & 12 & 16 \\
\hline University & 6 & 8 \\
\hline Total & 75 & 100 \\
\hline
\end{tabular}

Source: study survey 2013

Table 3.2 above revealed that there were a good number of respondents (6) (8\%) university graduates, while $33 \%$ did not totally attend to school. Educational attainment is most influential factor in women work. From the interview discussions, males in contrary were always having a bigger share of educational attainment 
and females were always disadvantaged and not seemed to be a target of education in the locality. This is shown in the records above where literacy was very clear in female respondents with $33 \%$ of the interviewees.

Table: 3.3 frequency distribution and percentage of respondents by marital status

\begin{tabular}{|c|c|c|}
\hline Marital status & Frequency & Percentage \\
\hline Single & 6 & 8 \\
\hline Married & 54 & 72 \\
\hline Divorced & 5 & 13 \\
\hline Widows & 10 & 100 \\
\hline Total & 75 & \\
\hline
\end{tabular}

Source: study survey 2013

The table 3.3 indicated that (54) $(72 \%)$ of respondents are shouldering the burden of supporting families and overwhelmed with impact of drought ad conflicts as most of men have migrated or died during and after the crises.

Table: 3.4 frequency distribution and percentage of respondents by their family members

\begin{tabular}{|c|c|c|}
\hline Family members & Frequency & Percentage \\
\hline $1-2$ members & 9 & 12 \\
\hline $3-4$ member & 13 & 17 \\
\hline $5-6$ members & 26 & 35 \\
\hline $7-8$ members & 17 & 23 \\
\hline More than 8 & 10 & 13 \\
\hline Total & 75 & 100 \\
\hline
\end{tabular}

Source: study survey 2013

The size of household $(\mathrm{HH})$ is a considerable factor in determining the productivity and wellbeing of the family. Effects of family members in livelihoods and coping mechanisms will be discussed latter under assets and strategies. Table 3.4 therefore, showed that 35\% of the household respondents having 5-6 members in the family which in coincidence with the estimates at Nidaa Al Sudan Organization (2012) for the households in the locality an indication of mis-use of women, girls and children in labour force.

Table: 3.5 frequency distribution and percentage of respondents by their residency

\begin{tabular}{|c|c|c|}
\hline Place of living/residence & Frequency & Percentage \\
\hline Village & 72 & 96 \\
\hline IDP with HC & 0 & 0 \\
\hline IDP in the camp & 2 & 3 \\
\hline Nomad & 1 & 1 \\
\hline Total & 75 & 100 \\
\hline
\end{tabular}

Source: study survey 2013

Table 3.5 indicated that $96 \%$ of the respondents were from villages in Al Goz locality, 3\% IDPs camping secretly near by the town of Dubeibat - capital of the locality hiding themselves in the community as the state is banning IDP camp settlement for political reasons.

Table: 3.1 frequency distribution and percentage of respondents by occupation before the crises

\begin{tabular}{|c|c|c|}
\hline Occupation & Frequency & Percentage \\
\hline Farmer & 43 & 57 \\
\hline Pastoralist & 3 & 4 \\
\hline Labour & 4 & 5 \\
\hline Official work & 25 & 33 \\
\hline Technician & 0 & 0 \\
\hline Total & 75 & 100 \\
\hline
\end{tabular}

Source: study survey 2013

Table 3.6 revealed that farming,as understood by the interviewees as cropping and vegetable production was the main choice for almost all respondents $57 \%$, and it was a major means of living for most of the population in the locality. 
Table: 3.7 frequency distribution and percentage of respondents by their role in supporting the family after the crises

\begin{tabular}{|c|c|c|}
\hline The role & Frequency & Percentage \\
\hline Firewood collection & 16 & 21 \\
\hline Brickmaking & 8 & 5 \\
\hline Casual labour & 4 & 23 \\
\hline Food+ tea selling & 17 & 11 \\
\hline Cattle herding & 8 & 13 \\
\hline Poultry farming & 10 & 16 \\
\hline Food processing & 12 & 100 \\
\hline Total & 75 & \\
\hline
\end{tabular}

Source: study survey 2013

Table 3.7 showed that respondents and their families, due to hardship of drought and conflicts, had to go in new productive activities to maintain themselves. After crises have impacted on the livelihoods, respondents adopted new strategies for survival; food and tea telling became a priority (23\%). Adult females, young girls and children were all grouped together to work and find solutions to their pressing wants and come to work together of separate in order to satisfy the family basic needs.

\subsection{Livelihood assets and strategies}

This section discusses types of crises and livelihood strategies adopted by respondents. Respondents were asked some questions about drought and conflicts, impacts, productive members in the family and main source of income before and after the crises to answer questions: what type of assets the lost and currently possess? What was the real cause/s of loss, and how that impacted on the wellbeing and coping mechanisms? The study discussed the questions as follows:Crises

Crises were too many as highlighted by the respondents in the questionnaires, interviews and focal group discussions. The study revealed that all respondents were in full agreement that the locality experienced a range of varying types of crises:

Conflicts and insecurity led to; reduction and/or in food production, income - earning activities, area and availability of land, greasing area, water resources for (animals and humans), social entitlements, social inequality/ equality

Drought and desertification led to: lowering of crops quality/ quantity, increase in food prices, loss of diary animals and livestock, problem in labour market, increase in rapid or organized migration of people, and loss of income

Both drought and conflicts collectively led to:

- Climate change/ little or no rain

- Famine and starvation

- Socio-economic changes including tribal conflicts and fighting

- Migration and displacement

- Socio-political changes as well have hit the locality and impacted on livelihoods

- Death of humans, child and mother mortality, death of elderly and the death of combatants as well as death of hungry people

- Social dis-orders (separations, divorce, family breakdown, displacement, migration and immigration)

- Economic losses; reduction in farm production, death of livestock, loss of properties, and complete destruction of infra-structure.

So, women as the bigger segment of the community have had to shoulder a higher percentage of sufferings of these crises and undermined in the adaptive strategies as pastoralists and farmers. Drought forced young women and their children (as productive members in the family and the state) to migrate to look for jobs or a new source of income after the crises. This forced migration made women and the girls child subject exploitation, hard labour, family breakdown with very little earning at the end.

\section{Conclusions}

The study concluded that crises; drought and conflicts have negatively impacted on the livelihoods of the people of South Kordofan State and in particular Al Goz locality. As all residents were either farmers or pastoralists, their means of living greatly affected during years of drought and conflicts, they had to sell out all belongings (jewelries, house furniture, etc.) to feed their children and other household members including those with special needs. Due to environmental degradation and reduction of forestry production especially charcoal 
and firewood, female heading families and young girls had to move far distances to secure cooking fuel and accordingly risking their lives as they experienced sexual assaults and in extreme being raped.

\section{Reference}

[1]. Abdurrahman Alsheref, the locality Commissioner (2012) an interview account.

[2]. Bogdan, R and Biklen, K (1982), Qualitative Research for Education: An Introduction to Theory and Method. By Allan and Baccon, Inc., 470 Atlantic Avenue, Boston, Massachusetts 02210. USA

[3]. FAO, (1994) Women, Agriculture and Rural Development: A Synthesis Report of the Africa Region, Rome.

[4]. Galtung John, (1996): Peace by Peaceful means, by London, SACE. UK

[5]. Karim Hussein and John Nelson, Sustainable livelihoods and Livelihood Diversification, IDS working paper 69. , 2004

[6]. http://ponce.sdsu.edu/three_issues_droughtfacts02.html, Drought Facts, the Ojos Negro Research Group.

[7]. https://per-1-imperialism-wiki.wikispaces.com/Population+of+Sudan. Secretariat General Papers: South Kordofan State Sudan Ministry of the Cabinet Affairs, 22 July 2008

[8]. Nuda Al Sudan Organization- a CBO - South Kordofan State- Annual report 2012

[9]. Peace Corps, September 2001, Disaster Preparedness and Mitigation: A Pre-Service Training Module. Information Collection and Exchange; Publication No.: T0123, by Center for Field Assistance and Applied Research Information Collection and Exchange.1111 20th Street, N.W. - Fifth Floor. Washington, D.C. 20526

[10]. SIHA, (July- 2007). Gender and Politics; A non-periodical journal published by Strategic Initiative for Women in Horn of AfricaSIHA.

[11]. South Kordofan State- Al Goz Locality District Records 2011

[12]. South Kordofan State- Al Goz Locality Metrological records 2008, 2010 and 2012

[13]. South Kordofan State, Sudan Ministry of the Cabinet Affairs, 22 July 2008

[14]. UNDP report: (2002), Understanding Poverty and Development in Africa- People living below the poverty line- printing press by the United Nations Development Programme1 UN Plaza, New York, NY 10017, USA 